James H. Carter, Creating a Chinese Harbin, Nationalism in an International City, 1916-1932

Ithaca and London, Cornell University Press, 2002, 217 pp.

\title{
Xiaohong Xiao-Planes
}

\section{OpenEdition}

\section{Journals}

Electronic version

URL: http://journals.openedition.org/chinaperspectives/651

DOI: 10.4000/chinaperspectives.651

ISSN: 1996-4617

\section{Publisher}

Centre d'étude français sur la Chine contemporaine

Printed version

Date of publication: 1 October 2003

ISSN: 2070-3449

\section{Electronic reference}

Xiaohong Xiao-Planes, « James H. Carter, Creating a Chinese Harbin, Nationalism in an International City, 1916-1932 », China Perspectives [Online], 49 | september-october 2003, Online since 17 January 2007, connection on 21 September 2020. URL : http://journals.openedition.org/chinaperspectives/651 ; DOI : https://doi.org/10.4000/chinaperspectives.651

This text was automatically generated on 21 September 2020

(c) All rights reserved 


\title{
James H. Carter, Creating a Chinese Harbin, Nationalism in an International City, 1916-1932
}

\author{
Ithaca and London, Cornell University Press, 2002, 217 pp.
}

\author{
Xiaohong Xiao-Planes
}

\section{EDITOR'S NOTE}

Translated from the French original by Nick Oates

1 A turntable for the Trans-Siberian and Trans-Manchurian railway lines, Harbin was built around 1898 by the Russians of the Chinese Eastern Railway Company. A prosperous city, it was home until the 1930s to residents of a dozen nationalities: Russians, Poles and other Europeans, Japanese and Koreans, etc., and Chinese in the majority.

2 Created by the Russians, with architectural and urban characteristics drawn from Europe, administered until the October Revolution by a foreign railway company, was Harbin a Russian or a Chinese city? The question continues to grate with Chinese nationalists, nostalgic writers and even the current authorities in Peking. The latter, anxious to control the nationalist discourse but also to keep alive the nation's memory, did not hesitate, in 1998, to cancel the opening of an international symposium dedicated to the commemoration of the town's centenary.

3 For James H. Carter, the debate misses the point: he prefers to focus his work on the evolution of the nationalism that emerged in Harbin. It is with no little vivacity and pertinence that he explores the efforts of the local actors who wish to affirm the Chinese identity of this "Russian city on Chinese soil", of this "Paris of the East"; but he finds it more judicious to place them in the context of a movement, the birth of which he dates to around 1916 and its decline to the eve of the Japanese occupation in 1932. 
In contrast to what happened in other Chinese cities of the same era, the militants of the Kuomintang (KMT) and of the Chinese Communist Party (CCP) played only a secondary, if not minimal, role in Harbin, and even that only materialised towards the end of the period in question. The nationalism of the city was built up by actors of various and sometimes unexpected types: teachers, publicists, merchants, railwaymen, students, Chinese Christians, Buddhists, regional officials and generals of the warlords... In the course of time and the historical context, the movement would undergo changes in its norms, inflections and physiognomy. To properly define the characteristics of its diverse manifestations, James H. Carter resorts to a series of binary terminological categories, such as "pro-foreigner" and "anti-foreigner", "modern" and "traditional", "religious" and "secular", "promotion of the nation state" and, quite simply, "promotion of the state".

5 A small, cosmopolitan group of men can be found at the original heart of the movement: they were often intellectuals or merchants, and the majority of them were Christians associated with the Young Men's Christian Association of America. In collaboration with the civil servants of the region, they planned in 1916 to build a secondary education institute-the Donghua School, which opened in 1918-in order to erect in Harbin a "Great Wall", with a view to arousing the conscience of the people, reinforcing the awareness of the Chinese identity and providing training in skills useful for the salvation of the nation. For this first generation (1916-1927) of Harbin nationalists, the Chinese (Confucian) and Western (Christian) cultures did not harbour any incongruities and were to be developed conjointly, far removed from any xenophobia and any rejection of the cosmopolitan heritage of the city.

6 But in the course of the 1920s, this "syncretic" nationalism gradually gave way to a more aggressive, more xenophobic nationalism. The White Russians, deprived of the status of extraterritoriality and the protection of a powerful neighbouring state, would suffer most particularly. The incident of the basketball match in 1926 between Russian and Chinese students perhaps marked the apogee of these new racial tensions. Supported by accounts and testimony from Russo-European observers, the author offers us page after page of excellent analysis. The repeated frictions were fed, on the Chinese side, by the hostility of the new political rulers and by the radicalism of the students. As for the foreigners, the fear of the "yellow peril" felt by the Westerners nourished fantasies of the "colonial culture" ("Chinese Rule in Foreign Eyes: Sex, Civilization, and Power", pp. 107-115).

7 There was another more fundamental change: if the social elite continued to co-operate with the regional authorities, those who held the civil and military power began to play an increasing role in the development of a sometimes derisive nationalist attitude. Each one, whether he was a customs administrator or the director of the special administration of the region of the eastern provinces, went to dedicated lengths to add national traits to a city centre virtually devoid of any Chinese physiognomy, taking the initiative to build particularly pompous constructions. The author devotes a fascinating chapter to this development, accompanied by a precise pinpointing of the locations, a description of the architectural styles and an analysis of the motivations of the sponsors ("A Chinese Place", Chinese Attempts to Claim Harbin's Physical Environment, 1921-1929", pp. 126-161). Secondary School No. 3, a large traditional Chinese building, was thus erected in the heart of Nangang, the district where the foreign consulates, companies and residents were concentrated. A splendid Buddhist Paradise Temple 
(Jilesi), and then a Confucian temple, find their place next door to the Russian and Jewish cemeteries, on either side of the main artery leading to the centre of the city. Sponsor of the Confucian temple, the civil administrator and military head Zhang Huanxiang went on to change, moreover, the Russian street names and ordered foreign shops and businesses to display signs in Chinese characters. Nevertheless, the Chinese authorities did not go so far as to demolish the Russo-European edifices; at the request of the White Russians, they even preserved the icons of Saint Nicholas affixed to certain buildings. In any case, the community in question no longer represented a threat to the local Chinese power.

While on this subject, the author pauses on the particular significance of the construction of a Confucian temple in Harbin. In fact, the socio-cultural function of the Confucian temples was declining in many Chinese towns during this same era. But the new Harbin needed to "reinvent the tradition". James H. Carter thus underlines a new form of nationalism, while at the same time drawing an uncommon picture of the representation of the state under the rule of the warlords.

9 Under the pressure exerted by the Japanese and as a result of the division among the Chinese authorities, this state nationalism was increasingly to cut itself off, around 1927-1928, from its social and political bases. Allying itself from this time on with Zhang Xueliang, the KMT dedicated itself to exploiting the anti-Japanese sentiment of the students on behalf of the nationalist Party-state. The complex games of a power struggle throw the population onto the wrong track. As for the local civil servants, anxious to preserve their prerogatives faced with the threat of the KMT, the majority of them would collaborate with the Japanese after the occupation in 1932.

Despite its initial originality, Harbin has experienced, in the nationalism of its Chinese inhabitants, an evolution that is comparable to that of the rest of China, from the construction of the nation state to the reinforcement of an authoritarian state, as the author very rightly recalls in his conclusion. 